\title{
Recurrent Staphylococcus warnerii prosthetic valve endocarditis: A case report and review
}

\author{
Ferhat Arslan*, Nese Saltoglu, Birgül Mete and Ali Mert
}

\begin{abstract}
To our knowledge, there have been only six S. warneri endocarditis cases reported in the English-language literature (Medline: 1966 to April 2011). We report a case of recurrent S. warneri endocarditis in a patient with prosthetic valve and silicon mammoplasty and we also review the relevant literature.
\end{abstract}

Keywords: Staphylococcus warneri endocarditis, prosthetic valve

\section{Introduction}

Coagulase-negative staphylococci (CoNS) have emerged in recent years as important nosocomial pathogens, with Staphylococcus epidermidis the most frequently recognized organism in this group [1]. S. warneri and other coagulase-negative staphylococci have been recognized less frequently as significant human pathogens [2].

S. warnerii can cause catheter-related bacteremia, native and prosthetic valve endocarditis (PVE), hematogenous vertebral osteomyelitis and ventriculoperitoneal shunt-associated meningitis [3-10]. S. warnerii is a CoNS that has rarely been reported in infective endocarditis. To our knowledge, there have been only six $S$. warneri endocarditis cases reported in the English-language literature (Medline: 1966 to April 2011). We report a case of recurrent $S$. warneri endocarditis in a patient with prosthetic valve and silicon mammoplasty and we also review the relevant literature.

\section{Case Report}

A 43-year-old immunocompetent woman presented with a 20-day history of fever and night sweats. On the physical examination, she had an axillary temperature of $38.5^{\circ} \mathrm{C}$, a heart rate of $90 / \mathrm{min}$, a blood pressure of $90 / 70 \mathrm{mmHg}$ and a diastolic murmur (2/4) at the aortic area. Routine chemistry panel and haemogram were normal. The Creactive protein $(\mathrm{CRP})$ level was $28 \mathrm{~g} / \mathrm{dl}($ normal $<5)$ and had an erythrocyte sedimentation rate (ESR) of $30 \mathrm{~mm} /$ hour. Three years ago, she had an aortic valve replacement

\footnotetext{
* Correspondence: ferhatarslandr@hotmail.com

Department of Infectious Diseases and Clinical Microbiology, Cerrahpasa Medical Faculty, Istanbul University, Turkey
}

for congenital aortic stenosis. She had a silicon mammoplasty and dental extraction nine months and four months ago respectively prior to this presentation. Three months ago, she had been treated for $S$. warneri endocarditis with ceftriaxone and gentamicin for four weeks. After one month of being discharged from the cardiology department, the patient developed fever and night sweats again. On the second day of last hospitalization, painful nodules (Oslers nodes) were noted in the pad of the right index finger. We initiated empirical infective endocarditis treatment with ampicillin-sulbactam and gentamicin. Transeosphageal echocardiography revealed motile vegetation (15 $\mathrm{mm} \times 4 \mathrm{~mm}$ in size) on the non-coronary cusp of the prosthetic aortic valve with no significant aortic incompetence. Three out of six blood culture bottles grew gram positive cocci in clusters, later identified as methicillinsensitive (CoNS) (subsequently identified as S. warneri). We used API ID 32 Staph system (a commercial test system strip consists of 32 cupules, 26 of which contain dehydrated biochemical media for colorimetric tests to identify staphylococci) (Bio-Merieux) for the definitive identification of this bacterium.

On the seventh day of the treatment for the second attack, she developed right hemiparesis and aphasia. Computed tomography analysis showed a hypodense lesion in the left fronto-temporal area compatible with infarction and cerebral angiography revealed an aneurysm at the bifurcation of the middle cerebral artery. The aneurysm was successfully obliterated by a neurosurgical intervention and hemorrhagic lesion eventually resolved. Ampicillin-sulbactam and gentamicin was continued for a total of eight weeks. She survived with minimal sequelae. 


\section{Discussion}

PVE is usually health care-related and the infection occurs in $1 \%$ to $3 \%$ of patients in the first postoperative year of valve surgery. PVE is caused by CoNS in approximately $15-40 \%$ of the cases. S. epidermidis is the most common organism associated with prosthetic valve endocarditis [11-13]. Especially, S. lugdunensis, S. capitis have several virulence factors and have been described to cause destructive native and prosthetic valve endocarditis [14-16]. S. warneri rarely causes septicemia and endocarditis. The case presented here is the seventh endocarditis case due to $S$. warneri reported in the literature $[4-7,9,10]$. The relevant clinical data regarding our case and the patients with $S$. warneri endocarditis reported in the literature are given in Table 1 . The mean age of patients was 57 and all except three had predisposing disease. Aortic valve was involved in six of the patients and two patients had concomitant mitral valve involvement. One patient had only mitral involvement. Vegetation was observed in all of the patients on ecocardiography. The mean duration of treatment was 6 weeks (4-8 weeks) and the beta-lactam and aminoglycoside combination was the preferred treatment choice. Three of the isolates were methicillin resistant but vancomycin sensitive. Ganesh D et al. were not reported their isolate sensitivity and the patient treated with nafcillin for 6 weeks [10].

A case with infective endocarditis (a 71-y-old male with a history of severe rheumatic aortic stricture, and replacement of the aortic valve by a mechanic prosthetic valve due to $S$. warneri has been reported by Abgrall $S$ al[7]. That patient was afebrile, and three blood cultures were negative. The patient was empirically treated intravenously with vancomycin and gentamicin. Twenty days later the patient went to the aortic valve replacement for increased transvalvular pressure gradient. Upon surgery, two vegetation tags and the valve revealed $S$. warneri on culture. In our case; S. warneri was isolated from blood during both the first and the second infective endocarditis attack.

The increasing use of prosthetic devices and intravascular catheters in contemporary healthcare has increased the importance of CoNS as a cause of prosthetic valve endocarditis. CoNS can colonize and produce a biofilm on a biomaterial. This is an important virulence factor in causing foreign body infections which are more indolent by nature. There are previously reported two cases of S. warneri endocarditis in which prosthesis (disc prosthesis) were thought to be the resource of infection $[6,9]$. Endocarditis took place nine months and one year after implantation, respectively. Our patient had silicon mammoplasty six months before the first attack. S. warneri endocarditis may directly develop due to procedures with foreign bodies for the heart such as prosthetic mechanic valve replacement, intracardiac defibrillator and pacemaker implantation besides other procedures with foreign bodies such as disk prosthesis. We thougt that $S$. warneri endocarditis may be associated with a catheter or other foreign materials such as silicon prosthesis/mechanic valve in the nosocomial setting.

As a conclusion; $S$ warneri infective endocarditis is an uncommon cause of infective endocarditis. This case report is important because of the recurrence of $S$. warneri endocarditis. The reason for recurrence of $S$. warneri endocarditis may be attributed to the biofilm occurrence on the foreign material and shortness of the treatment duration. The effective treatment should be maintained for at least 6-8 weeks for endocarditis due to S. warneri.

Table 1 Clinical features and prognosis of patients with Staphylococcus warneri endocarditis reported in the literature

\begin{tabular}{|c|c|c|c|c|c|}
\hline Reference & $\begin{array}{l}\text { Age/ } \\
\text { Gender }\end{array}$ & Predisposing condition & Valve involved & $\begin{array}{l}\text { Presence of vegetation } \\
\text { on echocardiography }\end{array}$ & Antibiotics and duration of therapy \\
\hline $4(1984)$ & $32 / \mathrm{M}$ & none & Aortic valve & Yes & $\begin{array}{l}\text { Penicilin+ Gentamicin } \\
\text { (4 weeks) }\end{array}$ \\
\hline 6(1989) & $66 / M$ & disc prosthesis ${ }^{* *}$ & $\begin{array}{l}\text { Mitral, Aortic } \\
\text { Valve }\end{array}$ & yes & $N A^{*}$ \\
\hline $3(1992)$ & $64 / M$ & none & $\begin{array}{l}\text { Mitral, Aortic } \\
\text { Pulmonary Valve }\end{array}$ & No & $\begin{array}{l}\text { Vancomicin+ } \\
\text { Gentamicin }\end{array}$ \\
\hline $7(2001)$ & $71 / \mathrm{M}$ & Prosthetic aortic valve & $\begin{array}{l}\text { Prosthetic aortic } \\
\text { valve }\end{array}$ & yes & $\begin{array}{l}\text { Vancomicin+ pefloxacine } \\
\text { (6 weeks) }\end{array}$ \\
\hline $9(2006)$ & $48 / M$ & disc prosthesis ${ }^{* *}$ & Aortic valve & yes & $\begin{array}{l}\text { Vancomicin+Fucidic acid } \\
\text { (three day) Then } \\
\text { Rifampicin+Fucidic acid }\end{array}$ \\
\hline $10(2011)$ & $78 / \mathrm{W}$ & none & Mitral valve & yes & Nafcicillin (6 weeks) \\
\hline $\begin{array}{l}\text { PRESENT } \\
\text { CASE(2008) }\end{array}$ & $43 / \mathrm{W}$ & $\begin{array}{l}\text { Prosthetic aortic valve, } \\
\text { silicon mamoplasty** }\end{array}$ & $\begin{array}{l}\text { Prosthetic aortic } \\
\text { valve }\end{array}$ & yes & $\begin{array}{l}\text { Ampicillin/sulbactam+ Gentamicin } 2 \\
\text { weeks, Then } 4 \text { weeks amp/sulb. } \\
\text { Ampicilin/sulbactam } \\
\text { ampicillin/sulbactam } \\
\text { (8 weeks) } \\
\text { Not done }\end{array}$ \\
\hline
\end{tabular}




\section{Consent}

Written informed consent was obtained from the patient for publication of this case report and accompanying images. A copy of the written consent is available for review by the Editor-in-Chief of this journal.

\section{Authors' contributions}

BM carried out the microbiological study, NS and FA followed the patient's clinical condition and wrote the paper. AM designed the study. All authors read and approved the final manuscript.

\section{Competing interests}

The authors declare that they have no competing interests.

Received: 31 December 2010 Accepted: 23 April 2011

Published: 23 April 2011

\section{References}

1. Stillman R, Wenzel R, Donowitz L: Emergence of coagulase negative staphylococci as major nosocomial blood stream pathogens. Infect Control 1987, , 8: 108-112.

2. Lowy F, Hammer S: Staphylococcus epidermidis infections. Ann Inter Med 1983, 99: 834-839.

3. Kamath U, Singer C, Isenberg HD: Clinical significance of Staphylococcus warneri bacteremia. J Clin Microbiol 1992, 30:261-4.

4. Dan M, Marine GJ, Goldsand G: Endocarditis caused by Staphylococcus warneri on a normal aortic valve following vasectomy. Can Med Assoc J 1984, 131:211-3.

5. Caputo GM, Archer GL, Calderwood SB, DiNubile MJ, Karchmer AW: Native valve endocarditis due to coagulase negative staphylococci. Clinical and microbiologic features. Am J Med 1987, 83:619-25.

6. Wood CA, Sewell DL, Strausbaugh LJ: Vertebral osteomyelitis and native valve endocarditis caused by Staphylococcus warneri. Diagn Microbiol Infect Dis 1989, 12:261-3.

7. Abgrall S, Meimoun P, Bun-Hoi A, Couetil JP, Gutmann L, Mainardi JL: Early prosthetic valve endocarditis due to Staphylococcus warneri with negative blood culture. J Infect 2001, 42:166.

8. Torre D, Ferraro G, Fiori GP, Martegani R, Speranza F, Tambini R, et al: Ventriculatrial shunt infection caused by Staphylococcus warneri: case report and review. Clin Infect Dis 1992, 14:49-52.

9. Stöllberger C, Wechsler-Fördös A, Geppert F, Gulz W, Brownstone E, Nicolakis $M$, et al: Staphylococcus warneri endocarditis after implantation of a lumbar disc prosthesis in an immunocompetent patient. J Infect 2006, 52:e15-e18.

10. Kini1 DGanesh, Ketan Patel, Parris RAddison, Tang SJane: An Unusual Presentation of Endocarditis Caused by Staphylococcus warneri. The Open Microbiology Journal 2010, 4:103-105.

11. Demitrovicova A, Hricak V, Karvay M, Krcmery V: Endocarditis due to coagulase-negative staphylococci: Data from a 22-years national survey. Scand J Infect Dis 2007, 39:655-656.

12. Lalani T, Kanafani ZA, Chu VH, Moore L, Corey GR, Pappas P, et al: International Collaboration on Endocarditis Merged Database Study Group. Prosthetic valve endocarditis due to coagulase-negative staphylococci: Findings from the International Collaboration on Endocarditis Merged Database. Eur J Clin Microbiol Infect Dis 2006, 25:365-368.

13. Wang A, Athan E, Pappas PA, Fowler VG Jr, Olaison L, Paré C, et al: International Collaboration on Endocarditis-Prospective Cohort Study Investigators. Contemporary clinical profile and outcome of prosthetic valve endocarditis. JAMA 2007, 297:1354-1361.

14. Zinkernagel AS, Zinkernagel MS, Elzi MV, Genoni M, Gubler J, Zbinden R, et al: Significance of Staphylococcus lugdunensis bacteremia: report of 28 cases and review of the literature. Infection 2008, 36(4):314-21.

15. Anguera I, Del Río A, Miró JM, Matínez-Lacasa X, Marco F, Gumá JR, et al: Hospital Clinic Endocarditis Study Group. and Hospital Clinic Endocarditis Study Group. Staphylococcus lugdunensis infective endocarditis: description of 10 cases and analysis of native valve, prosthetic valve, and pacemaker lead endocarditis clinical profiles. Heart 2005, 91(2):e10

16. Nalmas S, Bishburg E, Meurillio J, Khoobiar S, Cohen M: Staphylococcus capitis prosthetic valve endocarditis: report of two rare cases and review of literature. Heart Lung 2008, 37(5):380-4.

\section{doi:10.1186/1476-0711-10-14}

Cite this article as: Arslan et al:: Recurrent Staphylococcus warnerii prosthetic valve endocarditis: A case report and review. Annals of Clinical Microbiology and Antimicrobials 2011 10:14.

\section{Submit your next manuscript to BioMed Central and take full advantage of:}

- Convenient online submission

- Thorough peer review

- No space constraints or color figure charges

- Immediate publication on acceptance

- Inclusion in PubMed, CAS, Scopus and Google Scholar

- Research which is freely available for redistribution 